\title{
IMPACTS OF DIFFERENT RATES OF COMPOST, PROLINE-SPRAY AND IRRIGATION ON SOME SOIL PROPERTIES AND SUDAN GRASS GROWN IN SALINE SOIL
}

\author{
M.H. Abdel-Aal, D.M. khalifa and I.M. Abdalla \\ Soil, Water and Enviro.Res. Inst. (SWERI) - Agric. Res. C. (ARC), Giza- Egypt. \\ Received: Jul. 28,2018 \\ Accepted: Oct. 3, 2018
}

ABSTRACT: An experiment was conducted during the season of 2017, at South of Sahl El-Hosainiya Research Station, Agricultural Research Center (ARC) Sharkeia Governorate, Egypt. The experimental treatments were: Compost $(C)$ at rates control $\left(C_{0}\right)$, 24 ton. (C24) and 48 ton./ ha. (C48). Irrigation upon 25\% available moisture depletion (AMD) (I $\left.I_{25 \%}\right), 50 \%$ AMD $\left(I_{50 \%}\right)$ and $75 \%$ AMD $\left(I_{75 \%}\right)$. Proline treatments which included spray with $2 \mathrm{mg}$ Proline $L^{-1}\left(P_{1}\right)$ as well as No-Porline spray $\left(P_{0}\right)$. Whereas, spraying was done at the times 20, 45 and 60 days post-seeding (1200 L/ha.). The cultivated crop was Sudan grass. Two cuts were taken after 60and 120 days from sowing.

Obtained results showed that: Soil organic matter increased by $18.4 \%$ by $\left(C_{48}\right)$. Soil bulk density significantly decreased with the application of compost. Values of total porosity and hydraulic conductivity were significantly increased as a result of compost application. Available $N, P$ and $K$ in the soil at the end of experiment were greater in treatments receiving compost and irrigated upon depletion of $50 \%$ available water $\left(I_{50 \%}\right)$. Fresh and dry yield (two cut) were the highest with treatments of irrigation up to $50 \%$ depletion of water $\left(I_{50 \%}\right)$, compost at 48 ton/ha. $\left(C_{48 t o n}\right)$ and Proline-spray $\left(P_{1}\right)$.

Key wards: Compost, Prolene , Irrigation, Clay soil, Sudan grass.

\section{INTRODUCTION}

The recent policy of Egypt tended to increase and improve the arable area to and exploit the resources available.

Improvement of salt affected soils using amendment such as compost could be employed to maintain soil health, reduce pollution and increase agriculture productivity. Irrigated agriculture is vital for Egypt where rainfed agriculture does not represent any significant part of arable farming. Therefore, maximizing the return obtained from irrigation is very important. Compost has a positive effect on soil fertility and physical properties. It could also increase the irrigation water application efficiency.

Sudan grass are gained increasing importance as nan forage crop in many regions of the world including Egypt. They tolerate adverse conditions such as salinity, heat, drought, and low soil fertility. Abdel-Moez, et al., 1995, AbdelWahab, 1999, Badawi, 2003 and Rehan, et al., 2004 reported that application of organic amendments caused an increasing of soil EC from being about 0.3 to reach as much as about $2 \mathrm{dSm}^{-1}$, due to the release of soluble salts during their decomposition or due to contents of soluble salts inherent in the amendments. Torres-Tomejil (2008) found that, soil EC was not affected by application of organic amendments. Mekail (1994) treated a sandy soil with organic amendments and obtained an increase in soil organic matter. Moreover, Abdel-Aal et al. (2003) and Yaduvanshi (2003) found that the application of organic materials increased organic matter content in the soil. Modaihsh et al. (2005), Las TorresTomejil (2008) and Ibrahim et al. (2011) Patra et al. (1992) and El-Naggar (1996) 
reported low ammonification and nitrification in saline soils as compared with non-saline soils. Hamidi (1997) reported that low available- $\mathrm{N}$ in saline soils is due to decreased mineralization as well as to gaseous- $\mathrm{N}$ loss as ammonia. Abou-Baker (2008) applied banana residue compost to a calcareous soil and found that available- $\mathrm{N}$ increased in soil. Basyouny et al. (2004) reported that compost increased available-NPK in soil compared with mineral fertilizers. Singer et al. (2004) reported that compost application increased total soil $P$ to 164 $\mathrm{mg} \mathrm{kg}{ }^{-1}$ compared with $55 \mathrm{mg} \mathrm{kg}$ without compost. Taha (2007) applied sesame straw compost to a sandy soil and observed increases in available NPK after harvesting of two successive crops; the increase was proportional to the application.

Proline is the major amino acid associated with environmental stresses (salinity, extreme temperatures, UV radiation and heavy metals). When exposed to drought or a high salt content in the soil (both leading to water stress), many plants accumulate high amounts of proline, in some cases several times the sum of all the other amino acids (Ashraf and Foolad 2007). The protein genic amino acid-proline functions as an osmolyte, radical scavenger, electron sink, stabilizer of macromolecules and a cell wall component (Matysik et al. 2002).

\section{MATERIALS AND METHODS}

The current experimental study was conducted in South of Sahl El-Hosainiya Research Station, Agric. Res. Center (ARC), Sharkeia Governorate, Egypt during summer season of 2017 the experimental soil was saline sodic clay as shown in (Table 1). This investigation was conducted to evaluate the effect of compost and its interaction with treatments of irrigation and proline-spray on some soil characteristics. Also, to study the effects of these treatments on the forage crop (i.e. Sudan grass "Sudan grasssudanense" cv Giza 2). The yield of the two cuts of Sudan grass at 60 and 120 days after seeding were be detained for this purpose.

Table 1: Soil properties of the experiment site

\begin{tabular}{|c|c|c|c|}
\hline Particle size distribution & Values & Chemical analysis & Values \\
\hline Sand \% & 15.0 & $\mathrm{ECdSm}^{-1}$ soil past & 8.5 \\
\hline Silt \% & 39.7 & pH (1:25 w:v soil water) & 8.12 \\
\hline Clay \% & 45.3 & $\mathrm{Ca}^{2+} \quad(\mathrm{meq} / \mathrm{L})$ & 7.8 \\
\hline \multirow{2}{*}{ Texture class } & \multirow{2}{*}{ Heavy Clay } & $\mathrm{Mg}^{2+} \quad(\mathrm{meq} / \mathrm{L})$ & 5.5 \\
\hline & & $\mathrm{Na}^{+} \quad($ meq/L) & 67.4 \\
\hline Field capacity (\% w/w) & 50.2 & $\begin{array}{ll}\mathbf{K}^{+} \quad(\mathrm{meq} / \mathrm{L}) \\
\end{array}$ & 1.3 \\
\hline Wilting point (\% w/w) & 26.3 & $\mathrm{HCO}_{3}^{-(\text {meq/L) }}$ & 2.8 \\
\hline Available water(\%w/w) & 23.9 & $\mathrm{Cl}^{-} \quad($ meq/L) & 71.2 \\
\hline Saturation(\% w/v) & 81 & $\mathrm{SO}_{4}{ }^{2-} \quad($ meq/L) & 8.0 \\
\hline Bulk density(Mg m $\left.{ }^{-3}\right)$ & 1.65 & SAR & 26 \\
\hline Total porosity\% & 46.1 & \multicolumn{2}{|c|}{ Available nutrients $\left(\mathrm{mg} \mathrm{kg}^{-1}\right)$} \\
\hline Hydraulic Conductivity (cm h) & 0.44 & $\mathbf{N}$ & 56 \\
\hline $\mathrm{CaCO}_{3}(\mathrm{~g} / \mathrm{kg}$ soil) & 1.60 & $\mathbf{P}$ & 4.3 \\
\hline Organic matter ( $\mathbf{q} / \mathbf{k g}$ soil) & 0.63 & $\mathrm{~K}$ & 165 \\
\hline
\end{tabular}


The experimental design was a factorial split-plot design with three replicates. The main-plots assigned to irrigation treatments (I) and the sub-plots to the treatments of the organic fertilization (C) /proline (P) combinations. The three experimental factors rates were as follows:

(1) Irrigation "I "; with the three rates of:

- Irrigation depletion up to at $25 \%$ of soil available moisture (i.e. short irrigation intervals; $I_{25 \%}$ ).

- Irrigation depletion up to at $\mathbf{5 0 \%}$ (i.e. medium intervals; $I_{50 \%}$ ).

- Irrigation depletion up to at $75 \%$ (i.e. long intervals; $I_{75 \%}$ ).

(2) Organic fertilization "C"; with the three rates of:

- No compost (control) ( $\mathrm{C}_{0}$ )

- Compost added at 24 ton/ha. $\left(C_{24}\right)$.

- Compost added at 48 ton/ha. $\left(\mathrm{C}_{48}\right)$.

Their additions were followed by plugging under into the soil (within the $15-\mathrm{cm}$ soil plough layer) before seeding.

(3) Proline treatment "P"; with the two rates of:

- No proline-spray (spray with water; $\left.P_{0}\right)$.

- Proline-Spray $\left(P_{1}\right)$ with solution of 2 $\mathrm{mgL}^{-1}$ proline in 3 occasions at 500 L/fed. each time. Whereas the spraying were done at 20, 45 and 60 days after sowing.

The main plots (i.e. irrigation treatment) was separated from each other by $2 \mathrm{~m}$ belt. The area of the experimental plot was $10.5 \mathrm{~m}^{2}$.

All plots received $N, P$ and $K$ as follows: $170 \mathrm{~kg} \mathrm{~N}$ (as ammonium sulphate: $205 \mathrm{~g} \mathrm{~N} \mathrm{~kg}^{-1}$ ) + $24 \mathrm{~kg} \mathrm{P}$ (as ordinary Ca-superphosphate; $68 \mathrm{~g} \mathrm{P} \mathrm{kg}^{-1}$ ) +71 kg K (as K-sulphate; $400 \mathrm{~g} \mathrm{Kkg}^{-1}$ ). Application of $P$ and $K$ was done before sowing. Application of $\mathbf{N}$ was done in three equal doses (i.e. before sowing, two weeks and five weeks after sowing). Properties of compost and water (used for irrigation) are given in Table (2).

\section{Methods of analysis:}

\section{Soil analysis:}

Soil particle distribution was done using sodium hexameter-phosphate as a dispersing agent, by the international pipette method according to Piper (1950). Calcium carbonate was done using calcimeter and organic matter by the Walkley and Black method. Also pH (1:2.5 soil water suspensions) and salinity (in paste extract) were measured. Available $\mathrm{N}\left(\mathrm{NH}_{4} \cdot \mathrm{N}+\mathrm{NO}_{3}-\mathrm{N}\right)$ was extracted by $\mathrm{KCl}$ and determined by the Kjeldahl method. Soil bulk density, total porosity and saturation percent, all these determinations were according to methods cited by Black et al. (1965) and USDA (1954). Available $P$ and $K$ were extracted by Ammonium-Bicarbonateaccording to Soltanpour (1985). to Black et al. 1965).

Table (2): Properties of compost and the water of El-Salam canal.

A: Compost

\begin{tabular}{|c|c|c|c|c|c|c|c|c|c|c|}
\hline \multirow{3}{*}{$\begin{array}{c}\mathrm{EC}\left(\mathrm{dS} \mathrm{m^{-1 }}\right) \\
1: 10 \\
\text { extract. }\end{array}$} & \multirow{3}{*}{$\begin{array}{c}\text { pH } \\
1: 2.5 \\
\text { susp. }\end{array}$} & \multicolumn{3}{|c|}{ Nutrients } & \multirow{3}{*}{$\begin{array}{l}\mathrm{C} / \mathrm{N} \\
\text { ratio }\end{array}$} & \multirow{3}{*}{$\begin{array}{l}\text { O.M. } \\
\text { (\%) }\end{array}$} & \multirow{3}{*}{$\begin{array}{c}\text { Bulk } \\
\text { dens. } \\
\left(\mathrm{g} \cdot \mathrm{m}^{-3}\right)\end{array}$} & \multirow{3}{*}{$\begin{array}{c}\text { Moisture } \\
\text { (\%) }\end{array}$} & \multirow{3}{*}{$\begin{array}{l}\text { Ash } \\
\text { (\%) }\end{array}$} & \multirow{3}{*}{$\begin{array}{l}\text { W.H.C } \\
\text { (w/w) }\end{array}$} \\
\hline & & $\begin{array}{c}\text { Total } \\
(\%)\end{array}$ & \multicolumn{2}{|c|}{$\begin{array}{c}\text { Available } \\
\text { (mg/kg) }\end{array}$} & & & & & & \\
\hline & & $\mathbf{N}$ & $\mathbf{P}$ & $\mathrm{K}$ & & & & & & \\
\hline 4.55 & 6.67 & 2.73 & 38.3 & 286 & 13.57 & 49.01 & 0.455 & 15.34 & 54.6 & 1600 \\
\hline
\end{tabular}

B: Irrigation water

\begin{tabular}{|c|c|c|c|c|c|c|c|c|c|}
\hline \multirow{2}{*}{$\begin{array}{c}\mathrm{EC} \\
\left(\mathrm{dSm}^{-1}\right)\end{array}$} & $\mathrm{pH}$ & \multicolumn{7}{|c|}{ Soluble ions $\left(\mathrm{mq}_{\mathrm{c}} \mathrm{L}^{-1}\right)$} & \multirow{2}{*}{$\mathrm{SAR}$} \\
\cline { 3 - 10 } & $\mathrm{Ca}^{2+}$ & $\mathrm{Mg}^{2+}$ & $\mathrm{Na}^{+}$ & $\mathrm{K}^{+}$ & $\mathrm{HCO}_{3}{ }^{-}$ & $\mathrm{Cl}^{-}$ & $\mathrm{SO}_{4}{ }^{2-}$ & \\
\hline 1.92 & 7.63 & 3.55 & 3.6 & 11.37 & 0.37 & 3.01 & 12.34 & 3.55 & 6.61 \\
\hline
\end{tabular}




\section{Crop yield:}

Two cuts as sudan grass were taken from each plot after 60 and 120 days from sowing. Fresh and dray weight (oven dried at $70^{\circ} \mathrm{C}$ ) of plant of plant were determined.

\section{RESULTS AND DISCUSSION}

Chemical and physical characteristics of studded soil as well as the responses of both fresh and dry yields of the three harvests of Sudan grass, a forage crop, to evaluate the effect of compost additions, different irrigation rates and proline - application. Discussion will be covering the main individual effects of all the experimental factors, and interaction effects between them, for all the studied parameters.
Effects on some chemical characteristics of the tested saline soil:

\section{Soil Salinity:}

Salinity of soil at the end of the experimental trial, expressed as EC $\left(\mathrm{dSm}^{-1}\right)$, as affected by the experimental factors was showed in Table (3). Increasing the rate of compost addition significantly decrease soil salinity, whereas EC decreased with $17.9 \%$ at $\left(C_{24}\right)$ and with $22.02 \%$ at $\left(\mathrm{C}_{48}\right)$ relative to $\left(\mathrm{C}_{0}\right)$.

The lower of soil salinity with treatments received high rate of compost reflects the role of compost in retaining and maintaining soil moisture, thus reducing soil salinity.

Table (3): Soil salinity (EC, $d S m^{-1} 1: 2.5$ soil: water suspension) and soil $0 . \mathrm{M}(\%)$, after growing Sudan grass, as affected by the different experimental factors.

\begin{tabular}{|c|c|c|c|c|c|c|}
\hline \multicolumn{3}{|c|}{ Soil O.M (\%) } & \multicolumn{3}{|c|}{ Soil EC (dS/m) } & \multirow{3}{*}{$\begin{array}{c}\text { Compost (C) } \\
\text { (ton./ha) }\end{array}$} \\
\hline \multicolumn{6}{|c|}{ Irrigation Rates,$\%$ of available moisture depletion (I) } & \\
\hline$\left(\mathbf{I}_{75 \%}\right)$ & $\left(I_{50 \%}\right)$ & $\left(\mathrm{I}_{25 \%}\right)$ & $\left(I_{75 \%}\right)$ & $\left(I_{50 \%}\right)$ & $\left(I_{25 \%}\right)$ & \\
\hline \multicolumn{7}{|c|}{ Without - proline $\left(P_{0}\right)$} \\
\hline 0.63 & 0.63 & 0.63 & 8.00 & 8.00 & 8.00 & Control $\left(\mathrm{C}_{0}\right)$ \\
\hline 1.53 & 1.54 & 1.59 & 6.77 & 6.47 & 6.30 & Compost $\left(\mathrm{C}_{24}\right)$ \\
\hline 1.79 & 1.94 & 1.88 & 6.43 & 6.03 & 6.27 & Compost $\left(\mathrm{C}_{48}\right)$ \\
\hline \multicolumn{7}{|c|}{ Proline - spray , 2m/L $\left(P_{1}\right)$} \\
\hline 0.63 & 0.63 & 0.63 & 7.97 & 7.97 & 7.97 & Control $\left(\mathrm{C}_{0}\right)$ \\
\hline 1.55 & 1.58 & 1.61 & 6.73 & 6.37 & 6.70 & Compost $\left(\mathrm{C}_{24}\right)$ \\
\hline 1.72 & 1.93 & 1.92 & 6.47 & 5.93 & 6.23 & Compost $\left(\mathrm{C}_{48}\right)$ \\
\hline \multicolumn{3}{|c|}{$L S D$ at (0.05): $I^{*} C{ }^{*} P=n s$} & \multicolumn{4}{|c|}{$L S D$ at (0.05): $I+C \times P=n S$} \\
\hline
\end{tabular}

Mean values of the individual effects of the experimental factors.

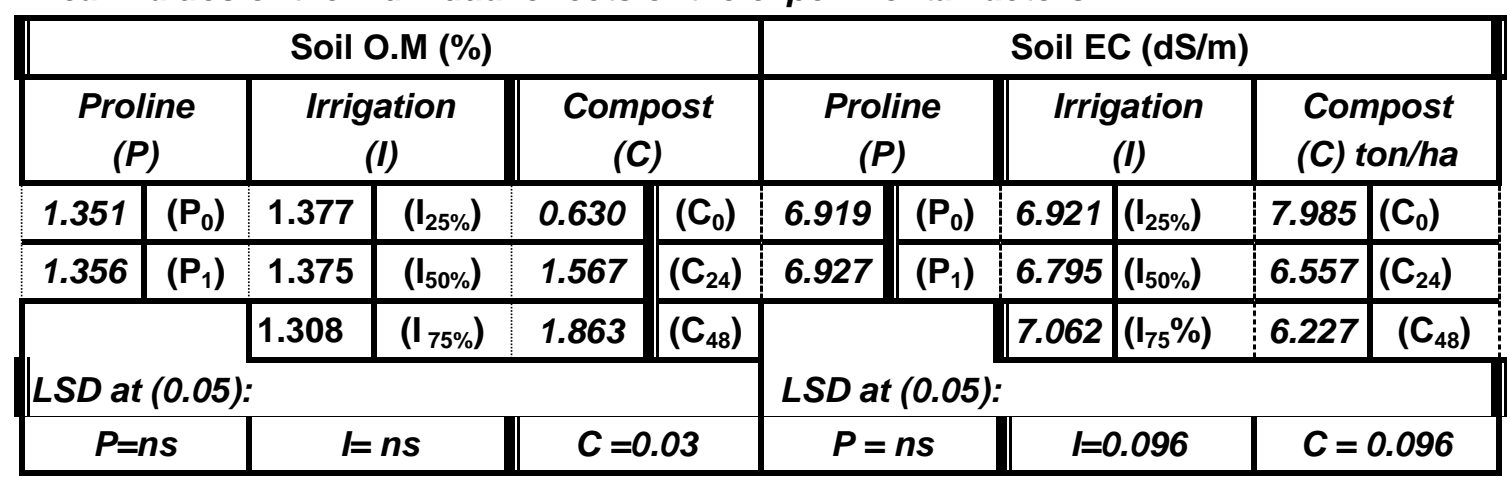


Treatments of irrigation (I) caused decreasing in EC of soil with $2.14 \%$ and $7.19 \%$ under $\left(\mathrm{I}_{25 \%}\right)$ and $\left(\mathrm{I}_{50 \%}\right)$ respectively. Comparing with $\left(\mathrm{I}_{75 \%}\right)$ decreased values of soil EC found was of observed with $25 \%$ or $50 \%$ of available moisture depletion (AMD) reflects the hampering of desalination of the top soil, due to closer between irrigation periods. On the other hand, sprayed plants with prolein didn't significantly affect EC of soil. Generally the decreasing in soil EC was more pronounced with compost addition (C) than with the other experimental factors of (I) or (P).

In general the experimental treatments the interaction effects between the experimental factors, showed nonsignificant trends with the lowest EC of soil (5.93) under $\left(\begin{array}{llll}I_{2} & P_{1} & C_{48}\end{array}\right)$ and the highest EC of soil abut (8) under nocompost addition $\left(C_{0}\right)$ regardless the rate of (I) or (P) treatments .

\section{Soil Organic matter content (\%):}

At the end of experiment, compost addition (C) was the most effective factor comparing with other experimental factors of (I) and (P). Whereas, the addition of compost caused significant increasing in soil organic matter (O.M.) content from $0.63 \%\left(C_{0}\right)$ to $1.57 \%\left(C_{24}\right)$ and $1.86\left(\mathrm{C}_{48}\right)$ with relative increasing (as $\%$ of $C_{0}$ ) of 149 and 195 , respectively. On the other hand treatments of irrigation (I) or proline (P) showed non-significant effects on O.M content (\%) of soil.

In general, content of soil O.M (\%) ranged from $0.63 \%$ under treatment of $\left(I_{25} C_{0} P_{0}\right)$ and $1.94 \%$ under the treatment of $\left(I_{50} C_{48} P_{0}\right)$.

\section{Available nitrogen, phosphorus and potassium of Soil:}

Available values of $N, P$ and $K$ of soil at the end of the experimental trial, expressed as $\left(\mathrm{mg} \mathrm{kg}^{-1}\right)$, as affected by the experimental factors were showed in Table (4).
Available - N:

Compost addition resulted an increasing in available- $\mathrm{N}$ the average values were 220 and $293 \%$ relative to $\left(C_{0}\right)$ in plots of soil treated with $\left(\mathrm{C}_{24}\right)$ and $\left(\mathrm{C}_{48}\right)$ respectively.

Irrigation treatments showed the highest effect on available-N under $\left(\mathrm{I}_{75} \%\right)$ comparing with other irrigation treatments (i.e. $I_{25 \%}$ and $I_{50 \%}$ ). The favorable effect of $\left(I_{75} \%\right)$ was the most effective treatment under conditions of no- proline in combination with compost application.

Proline- spray $\left(P_{1}\right)$ showed a decrease on available- $\mathrm{N}$ with $9 \%$ relative to $\left(P_{0}\right)$. It is noticed that, available- $\mathrm{N}$ in presence of $\left(\mathrm{C}_{24}\right)$ or $\left(\mathrm{C}_{48}\right)$ under irrigation with $\left(\mathrm{I}_{25} \%\right)$ or $\left(\mathrm{I}_{75} \%\right)$ showed non-significant changes under Porlien-spray $\left(P_{1}\right)$ comparing with under $\left(\mathbf{P}_{0}\right)$.

Generally, available-N of soil as affected with the triple interaction varied considerably according to the applied treatment. Whereas, it's values ranged between $56 \mathrm{mg} \mathrm{N} \mathrm{kg}^{-1}$ soil ( $\mathrm{C}_{0}$ under any treatments of I or $P$ ) to $278.3 \mathrm{mg} \mathrm{N} \mathrm{kg}^{-1}$ in soil of plots treated with $\left(C_{48} I_{50 \%} P_{0}\right)$ with an increase of $397 \%$ for the latter over the former treatment.

\section{Available - $P$ :}

Compost addition increased available$P$ with averaging values of $150 \%$ and $250 \%$, relative to $\left(C_{0}\right)$, in treatments receiving $\left(\mathrm{C}_{24}\right)$ and $\left(\mathrm{C}_{48}\right)$ respectively.

Under irrigation treatments of $\left(\mathrm{I}_{25 \%}\right)$ and $\left(\mathrm{I}_{75 \%}\right)$, the experimental soil had the similar values of available-P. Moreover, $\left(I_{50 \%}\right)$ showed more available-P with $\left(I_{25 \%}\right)$ or $\left(\mathrm{I}_{75 \%}\right)$ with $22 \%$. The favorable effect of $\left(I_{50 \%}\right)$ over $\left(I_{25 \%}\right.$ or $\left.I_{75 \%}\right)$ occurred only when compost was applied. Such positive effect was greater under $\left(C_{48}\right)$ than $\left(C_{24}\right)$. 


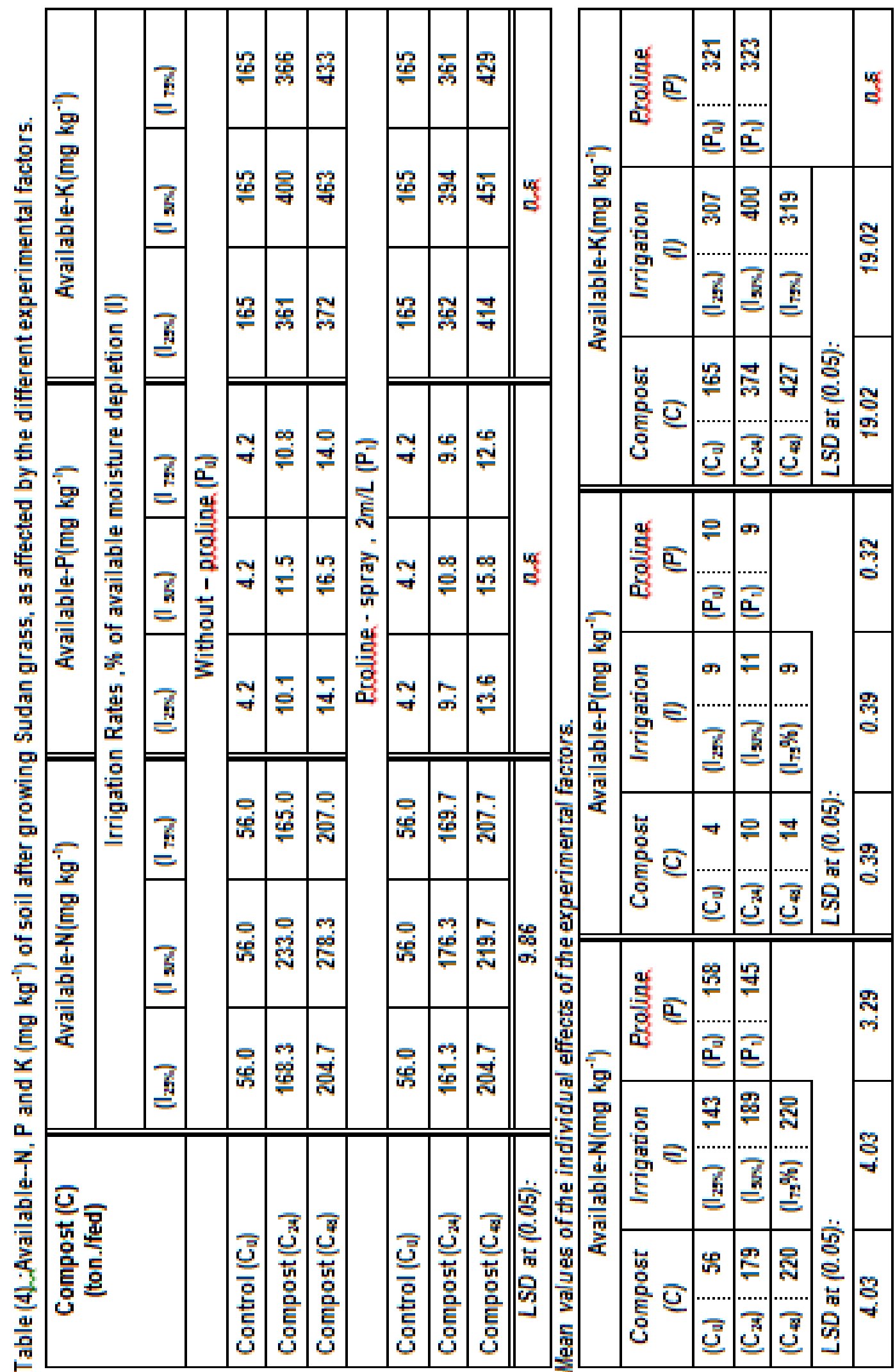


The spraying of proline $\left(P_{1}\right)$ resulted in lower of soil P-availability by a significant average of $11 \%$. This occurred under all conditions of compost addition and irrigation treatment no significant effect of was observed by either (C) or (I or both on the response to proline.

The available-P varied considerably according to the applied treatments. Values ranged between $4.2 \mathrm{mg} \mathrm{P} \mathrm{kg}^{-1}\left(\mathrm{C}_{0}\right.$ I $P)$ to $16.5 \mathrm{mg} \mathrm{P} \mathrm{kg}^{-1}\left(\mathrm{C}_{48} \mathrm{I}_{50 \%} \mathrm{P}_{0}\right)$ with an increase of $293 \%$ due to the latter treatment higher than the former one.

Available - $K$ :

Compost addition resulted in increases in available- $K$ averaging 127 to $158 \%$ in treatments receiving $\left(C_{24}\right)$ and $\left(C_{48}\right)$ respectively, relative to $\left(C_{0}\right)$.

Irrigation treatment (I $50 \%$ ) gave the highest available $-\mathrm{K}$ over $\left(\mathrm{I}_{75 \%}\right)$ or $\left(\mathrm{I}_{25 \%}\right)$. Soils treated with $\left(I_{25 \%}\right)$ or $\left(I_{75 \%}\right)$ recorded the smallest available-k with nonsignificant interaction between them. The $I_{50 \%}$ irrigation treatment showed greater value of average available $-K \quad(30 \%)$ comparing to contents of $\mathrm{I}_{25 \%}$ and $\mathrm{I}_{75 \%}$ treatments respectively. The effect of proline was not significant.

No significant interactions were shown (i.e. effect of irrigation) compost or proline was not interfered by the other factor. But, soil available-K varied according to the applied treatments with values ranging between $165 \mathrm{mg} \mathrm{K} \mathrm{kg}^{-1}\left(\mathrm{C}_{0}\right.$ I P) to $463 \mathrm{mg} \mathrm{K} \mathrm{kg}^{-1}\left(C_{48} \mathrm{I}_{50 \%} \mathrm{P}_{0}\right)$. The highest treatment showed an increase of $181 \%$ over the lowest one.

Experimental factors effects on the previous discussed chemical characteristics:

The highest EC value, under $\mathrm{I}_{75 \%}$ treatment, denote the relatively low soil of soil for moisture content treatment relative to the other two treatments.

On the other hand, low EC of $\left(\mathrm{I}_{25 \%}\right)$ and $\left(I_{50 \%}\right)$ reflect a possible greater leaching of salts from those two treatments relative to $\left(I_{75 \%}\right)$. Decreased in soil salinity by applied compost is due to increased retention of soil moisture.

Increased organic matter and available NPK by compost application are a direct effect of compost and nutrients associated with it (Las Torres-Tomejil, 2008). More nutrients associated with $I_{50 \%}$ greater than $\mathrm{I}_{25 \%}$ or $\mathrm{I}_{75 \%}$ is an indication of more suitable conditions in soil of that treatment which would accelerate the decomposition of organic matter and maximize nutrients contents, in the soil especially NPK. Sarker et al. (1992) found that, the compost provided a substantial modification of physical and chemical properties, which have positive effects on soil fertility. Bulluck et al., (2002) attributed increased availability of nutrients upon adding compost, to an increase of exchange sites of the organic colloids.

Effects on some soil physical characteristics of the tested saline soil:

Some soil physical characteristics of the tested soil at the end of the experimental trial as affected by the experimental factors, such are Soil bulk density (BD), soil total porosity (TP) and soil hydraulic conductivity (HC), will be studied and presented in Table (5).

Soil bulk density (BD):

Bulk density was decreased with compost application. The average increase ranging between 24.7 and $32.9 \%$ due to applying $\left(\mathrm{C}_{24}\right)$ and $\left(\mathrm{C}_{48}\right)$ respectively.

Applied treatments caused variation on Soil bulk density (BD), at the end of experiment Bulk density values $\left(\mathrm{g}_{\mathrm{m}} \mathrm{m}^{-3}\right)$ ranged between 1.11 and 1.72 for $\left(I_{50 \%} C_{48}\right.$ $\mathrm{P1})$, and $\left(\begin{array}{lll}\mathbf{I}_{25 \%} & \mathrm{C}_{0} & \mathrm{P}_{0}\end{array}\right)$ and $\left(\mathrm{I}_{25 \%} \mathrm{co}_{0} \mathrm{P} 1\right)$ respectively. 


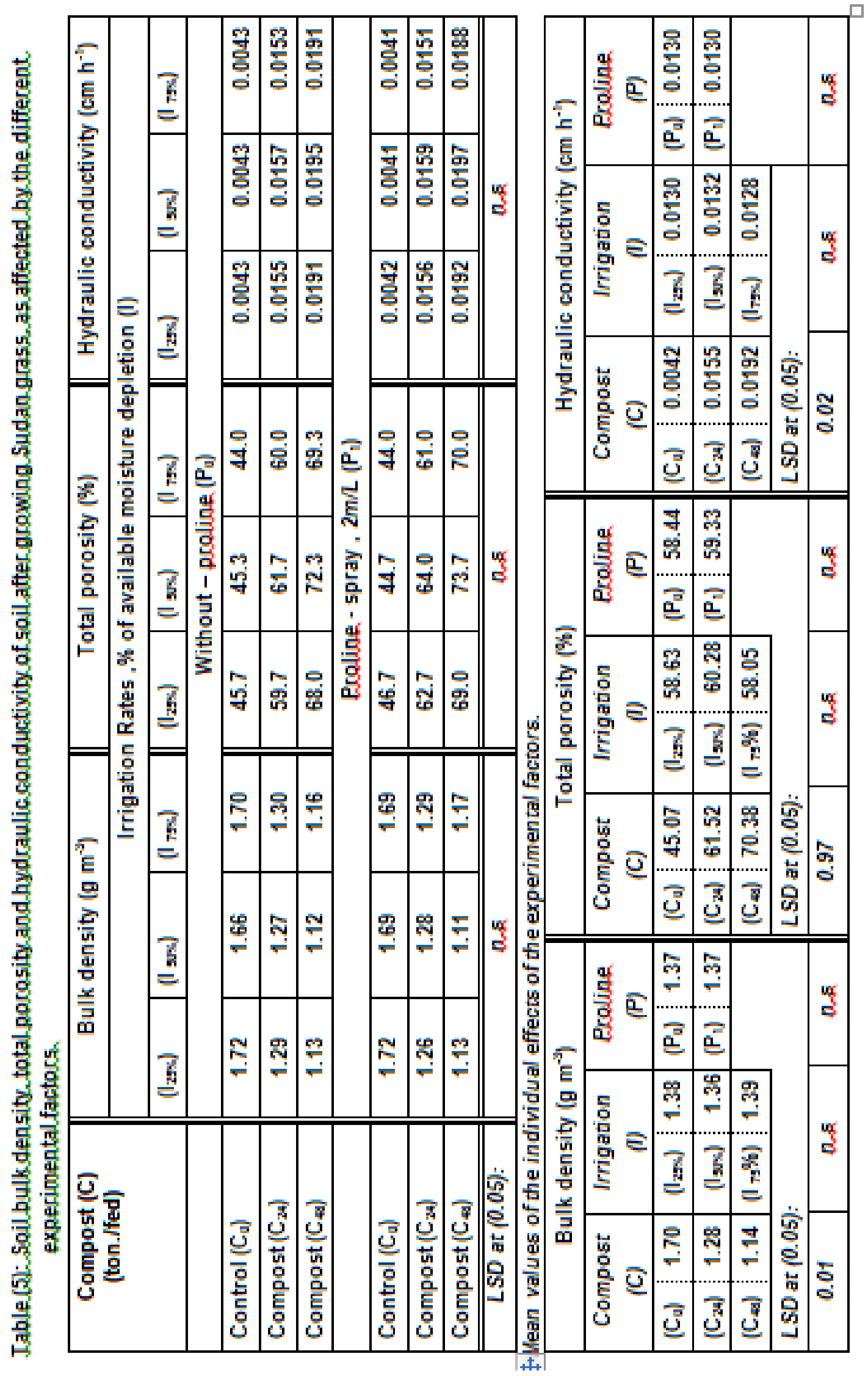


The lowest BD exists with the highest rate of compost application $\left(\mathrm{C}_{48}\right)$ rate, irrigated by the most suitable irrigation (I $\left.{ }_{50 \%}\right)$, and sprayed with proline $\left(P_{1}\right)$ which enhanced growth of plant, all such conditions contributed in improving soil physical condition in the root zone. Irrigation treatment $\left(I_{50 \%}\right)$ showed, in general, slightly lower BD than the other irrigation treatment.

The effect of proline $(P)$ showed nonsignificant trends with respect to soil bulk density. Therefore, the most effective treatment, which decreased BD, was the addition of organic materials which enhanced soil aggregation and increase the apparent soil volume and consequently decrease bulk density (Gouda, 1984, Las Torres-Tomejil 2008 and Mbah and Onweremadu 2009).

\section{Soil total porosity (TP):}

The pattern of response of total porosity (TP) to applied treatments is exactly the same like that of the BD, but with an opposite trend (since increased porosity is another expression of a decreased $\mathrm{BD}$ and TP ranged from $44.0 \%$ $\left(\mathbf{I}_{75 \%} \mathbf{C}_{0} \mathbf{P}_{0}\right)$ or $\left(\mathbf{I}_{75 \%} \mathbf{C}_{0} \mathbf{P}_{1}\right)$ to $\mathbf{7 3 . 7} \%$ $\left(I_{50 \%} \mathrm{C}_{48} \mathrm{P}_{1}\right)$. No significant variations of TP values were observed as a result of either irrigation (I) or proline spray $\left(P_{0}\right)$. Compost showed TP increases with average of 36.5 and $56.2 \%$ for $\left(C_{24}\right)$ and $\left(\mathrm{C}_{48}\right)$ application respectively. Such increase is an indicator of soil aggregation and reflect the improvement of soil structure and the increase of porosity. (Las Torres-Tomejil 2008).

Soil hydraulic conductivity (HC):

Hydraulic conductivity at the end of experiment showed variation depending on applied treatment, values ranged between $0.0041\left(I_{50} C_{0} P_{1}\right)$ or $\left(I_{75} C_{0} P_{1}\right)$ to $0.0197 \mathrm{~cm} \mathrm{~h} \mathrm{~h}^{-1}\left(\mathrm{I}_{50} \quad \mathrm{C}_{48} \quad \mathrm{P}_{1}\right)$. Irrigation treatments showed non-significant effects. Increased HC by addition compost is a direct effect of increased porosity caused by manuring. (Hillel, 1982, Aziz, et al. 1999 and Hamouda, et al. 1999).

Overall assessment of the experimental factors effects on the previous discussed physical characteristics:

Compost showed positive effect, of its $\mathrm{C}_{24}$ and $\mathrm{C}_{48}$ doses, giving progressive increase over the no compost treatment $\left(C_{0}\right)$, with descending order of $\left(: C_{48}>C_{24}\right.$ $>\mathrm{C}_{0 .}$.)

The treatment of compost addition at the high rate showed the lowest bulk density and the highest total porosity reflecting the effect of organic matter in improving soil physical properties particularly in heavy clay soil. Mbagwu (1992) showed that the decrease in bulk density of soil due to compost is a direct effect of increased organic matter in soil. Organic amendments promote soil hydraulic activity and build up soil structure of favorable effect to plant growth (Charreau and Nicou, 1971).

The highest positive response to irrigation was associated with $I_{50 \%}$, ( i.e. irrigation upon $50 \%$ available moisture depletion AMD) comparing with $\mathrm{I}_{1}$ ( i.e. irrigation upon $25 \%$ AMD which was the lowest) or with the $\mathrm{I}_{75 \%}$, i.e. irrigation upon $75 \%$ AMD : in an order of $I_{2}>I_{3}>I_{1}$. Proline treatment $\left(P_{1}\right)$ showed positive effect relative to the no proline treatment $\left(P_{0}\right)$, in an order of $P_{1}>P_{0}$, under all conditions.

Effect on fresh weight of Sudan grass ( $1^{\text {st }}$ and $2^{\text {nd }}$ cut):

Fresh weight of $1^{\text {st }}$ cut:

As shown in Table (6), fresh weight varied considerably according to the experimental treatment. Compost addition resulted in increases fresh weight of 21.3 and $36.0 \%$ for $\mathrm{C}_{24}$ and 
$\mathrm{C}_{48}$ respectively. Whereas, irrigation upon $25 \%\left(I_{25 \%}\right)$ gave the lowest yield while the $I_{50 \%}$ gave the highest; with an order of $I_{50 \%}$ $>I_{75 \%}>I_{25 \%}$, and average increases were $23.4 \%$ and 8.2 at $I_{50 \%}$ and $I_{75 \%}$, respectively compared to $I_{25 \%}$.On the other hand, spraying proline $\left(P_{1}\right)$ gave $9 . \%$ as an average increase.

Generally, fresh weigh of $1^{\text {st }}$ cut Sudan grass ranged from $42.1 \mathrm{Mg} \cdot \mathrm{ha}^{-1}\left(\mathrm{I}_{25 \%} \mathrm{C}_{0} \mathrm{P}_{0}\right)$ to $77.5 \mathrm{Mg} \mathrm{ha}^{-1}\left(\mathrm{I}_{50 \%} \mathrm{C}_{48} \mathrm{P}_{1}\right)$. Positive effect of compost application, as well as porline - spray, was occurred under all conditions. The interactions were not significant, Also the highest yield given by the medium irrigation of $\mathrm{I}_{50 \%}$ and the lowest given by the wettest one $I_{25 \%}$ occurred without interaction by compost application or proline - spray $\left(\mathbf{P}_{1}\right)$.
Fresh weight of $2^{\text {nd }}$ cut:

The pattern of response was rather similar to that of the first cut with yields varying between $35.1 \mathrm{Mg} \mathrm{ha}^{-1}\left(\mathrm{I}_{25 \%} \mathrm{C}_{0} \mathrm{P}_{0}\right)$ to $69.9 \mathrm{Mg} \mathrm{ha}^{-1}\left(\mathrm{I}_{50 \%} \mathrm{C}_{48} \mathrm{P}_{1}\right)$.

Compost addition resulted in increased values of 24.9 and $\mathbf{4 1 . 2} \%$ for $\mathrm{C}_{24}$ and $\mathrm{C}_{48}$ respectively. Irrigation treament $I_{50 \%}$ gave the highest fresh weight and $\mathrm{I}_{25 \%}$ gave the lowest one with an order of $I_{50 \%}>I_{25 \%}>I_{25 \%}$ with an average increases of and $27.6 \%$ and 5.5 by $\mathrm{I}_{25 \%}$ and $\mathrm{I}_{57 \%}$, respectively $\mathrm{I}_{25 \%}$. Spraying of proline $\left(P_{1}\right)$ gave an average of $9 \%$ comparing to control.

The interactions effect, of the three experimental factors (i.e. irrigation, compost and proline), was not affected by the status of each other's, (i.e. no interaction effect was found)

Table (6): Fresh weight of $1^{\text {st }}$ and $2^{\text {nd }}$ cut $\left(\mathrm{Mgha}^{-1}\right)$ of Sudan grass as affected by the different experimental factors.

\begin{tabular}{|c|c|c|c|c|c|c|}
\hline \multirow{3}{*}{$\begin{array}{c}\text { Compost (C) } \\
\text { (ton./ha) }\end{array}$} & \multicolumn{3}{|c|}{$1^{\text {st }}$ cut $\left(M g h a^{-1}\right)$} & \multicolumn{3}{|c|}{$2^{\text {nd }}$ cut $\left(M g h a^{-1}\right)$} \\
\hline & \multicolumn{6}{|c|}{ Irrigation Rates,$\%$ of available moisture depletion (I) } \\
\hline & $\left(I_{25 \%}\right)$ & $\left(I_{50 \%}\right)$ & $\left(I_{75 \%}\right)$ & $\left(\mathrm{I}_{25 \%}\right)$ & $\left(I_{50 \%}\right)$ & $\left(I_{75 \%}\right)$ \\
\hline \multicolumn{7}{|c|}{ Without - proline $\left(P_{0}\right)$} \\
\hline Control $\left(\mathrm{C}_{0}\right)$ & 42.1 & 47.4 & 45.6 & \begin{tabular}{|r|}
35.1 \\
\end{tabular} & 42.1 & 39.1 \\
\hline Compost $\left(\mathrm{C}_{24}\right)$ & 52.2 & 65.5 & 56.7 & 45.6 & 58.9 & 50.1 \\
\hline Compost $\left(\mathrm{C}_{48}\right)$ & 58.3 & 74.4 & 63.3 & 51.6 & 66.7 & 55.6 \\
\hline \multicolumn{7}{|c|}{ Proline - spray , $2 \mathrm{~m} / \mathrm{L}\left(\mathrm{P}_{1}\right)$} \\
\hline Control $\left(\mathbf{C}_{0}\right)$ & 49.2 & 58.7 & 52.7 & 40.5 & 51.1 & 45.4 \\
\hline Compost $\left(\mathrm{C}_{24}\right)$ & 55.5 & 69.2 & 59.7 & 48.0 & 62.3 & 51.5 \\
\hline Compost $\left(\mathrm{C}_{48}\right)$ & 62.3 & 77.5 & 66.4 & 54.2 & 69.9 & 60.5 \\
\hline \multicolumn{4}{|c|}{$L S D$ at (0.05): $I_{\star} C * P=n S$} & \multicolumn{3}{|c|}{ LSD at (0.05): $I^{\star} C{ }^{*} P=n s$} \\
\hline
\end{tabular}

Mean values of the individual effects of the experimental factors.

\begin{tabular}{|c|c|c|c|c|c|c|c|c|c|c|c|}
\hline \multicolumn{6}{|c|}{$1^{\text {st }}$ cut $\left(M g h a^{-1}\right)$} & \multicolumn{6}{|c|}{$2^{\text {nd }}$ cut $\left(M g h a^{-1}\right)$} \\
\hline \multicolumn{2}{|c|}{$\begin{array}{c}\text { Compost } \\
\text { (C) }\end{array}$} & \multicolumn{2}{|c|}{$\begin{array}{l}\text { Irrigation } \\
\text { (I) }\end{array}$} & \multicolumn{2}{|c|}{$\begin{array}{l}\text { Proline } \\
(P)\end{array}$} & \multicolumn{2}{|c|}{$\begin{array}{l}\text { Compost } \\
\text { (C) }\end{array}$} & \multicolumn{2}{|c|}{$\begin{array}{l}\text { Irrigation } \\
\text { (I) }\end{array}$} & \multicolumn{2}{|c|}{$\begin{array}{l}\text { Proline } \\
(P)\end{array}$} \\
\hline$\left(C_{0}\right)$ & 49.28 & $\left(\mathrm{I}_{25 \%}\right)$ & 53.03 & $\left(P_{0}\right)$ & 56.17 & $\left(C_{0}\right)$ & 42.22 & $\left(\mathrm{I}_{25 \%}\right)$ & 45.83 & $\left(\mathbf{P}_{0}\right)$ & 49.42 \\
\hline$\left(C_{24}\right)$ & 59.80 & $\left(I_{50 \%}\right)$ & 65.45 & $\left(\mathbf{P}_{1}\right)$ & 61.24 & $\left(C_{24}\right)$ & 52.73 & $\left(I_{50 \%}\right)$ & 58.50 & $\left(P_{1}\right)$ & 53.88 \\
\hline$\left(\mathrm{C}_{48}\right)$ & 67.03 & $\left(\mathrm{I}_{75} \%\right)$ & 57.40 & & & $\left(\mathrm{C}_{48}\right)$ & 59.60 & $\left(I_{75 \%}\right)$ & 48.34 & & \\
\hline \multicolumn{6}{|c|}{ LSD at (0.05): } & \multicolumn{6}{|c|}{ LSD at (0.05): } \\
\hline \multicolumn{2}{|c|}{$C=1.76$} & \multicolumn{2}{|l|}{$I=1.76$} & \multicolumn{2}{|c|}{$P=1.44$} & \multicolumn{2}{|c|}{$C=1.7$} & \multicolumn{2}{|c|}{$I=1.7$} & \multicolumn{2}{|c|}{$P=1.39$} \\
\hline
\end{tabular}


Effects of experimental treatments on dry weight of Sudan grass $\left(1^{\text {st }}\right.$ and $2^{\text {nd }}$ cut):

\section{Data in Table (7) showed that} the dry weight of $1^{\text {st }}$ and $2^{\text {nd }}$ cut affected by deferent experimental treatments.

Dry weight of $1^{\text {st }}$ cut:

Compost gave increases about 27.4 and $47.4 \%$ in treatments receiving $\left(C_{24}\right)$ and $\left(\mathrm{C}_{48}\right)$ respectively. Irrigation treatments showed this order: $I_{50 \%}>I_{75 \%}>I_{25 \%}$, with average increases of 22.6 and $4.6 \%$ at $\mathrm{I}_{50 \%}$ and $\mathrm{I}_{75 \%}$ respectively compared to $\mathrm{I}_{25 \%}$ Proline spray $\left(\mathrm{P}_{1}\right)$ increased the yield by an average of 9.6 $\%$. On the other hand the positive effect of proline was of less magnitude than control treatment of compost such values were 3.4 and $5.7 \%$ under treatments of $\mathrm{C}_{24}$ and $\mathrm{C}_{48}$ respectively.
Dry weight varied considerably from $7.7 \mathrm{Mg} \mathrm{ha}^{-1}$ to $15.9 \mathrm{Mg} \mathrm{ha}^{-1}$ (i.e. $106 \%$ increase.) as a result of treatments of $\left(I_{25 \%} C_{0} P_{0}\right)$ and $\left(I_{50 \%} C_{48} P_{1}\right)$,respectively.

Dry weight of $2^{\text {nd }}$ cut:

Dry weight was increased with compost application from 34.0 to $52.8 \%$ for $\mathrm{C}_{24}$ and $\mathrm{C}_{48}$ respectively. Irrigation treatments in their effect on dry weight were of the order $I_{50 \%}>I_{75 \%}>I_{25 \%}$, with average increases of 24.3 and $10.4 \%$ at $I_{2}$ and $I_{3}$ respectively compared to $I_{1}$. Spraying proline $\left(\mathrm{P}_{1}\right)$ gave $8.8 \%$ average increase. Such increase was greater under the $\mathrm{I}_{75 \%}$ irrigation (13.2\%); also proline was showed greater positive effect under no compost application (22.4\%).

The general trend of dry weight varied considerably according to the applied treatments ranging between $6.6 \mathrm{Mg} \mathrm{ha}^{-1}$ $\left(\mathrm{I}_{25 \%} \mathrm{C}_{0} \mathrm{P}_{0}\right)$ to $13.9 \mathrm{Mg} \mathrm{ha}^{-1}\left(\mathrm{I}_{50 \%} \mathrm{C}_{48} \mathrm{P}_{1}\right)$; $111 \%$ increase.

Table (7): Dry weight of $1^{\text {st }}$ and $2^{\text {nd }}$ cut $\left(\mathrm{Mgha}^{-1}\right)$ of Sudan grass as affected by the different experimental treatments.

\begin{tabular}{|c|c|c|c|c|c|c|}
\hline \multirow{3}{*}{$\begin{array}{c}\text { Compost (C) } \\
\text { (ton./ha) }\end{array}$} & \multicolumn{3}{|c|}{$1^{\text {st }}$ cut $\left(M g h a^{-1}\right)$} & \multicolumn{3}{|c|}{$2^{\text {nd }}$ cut $\left({\left.M g h a^{-1}\right)}^{\prime}\right.$} \\
\hline & \multicolumn{6}{|c|}{ Irrigation Rates,$\%$ of available moisture depletion (I) } \\
\hline & $\left(I_{25 \%}\right)$ & $\left(I_{50 \%}\right)$ & $\left(I_{75 \%}\right)$ & $\left(\mathbf{I}_{25 \%}\right)$ & $\left(\mathbf{I}_{50 \%}\right)$ & $\left(I_{75 \%}\right)$ \\
\hline \multicolumn{7}{|c|}{ Without - proline $\left(P_{0}\right)$} \\
\hline Control $\left(\mathbf{C}_{0}\right)$ & 7.7 & 9.8 & 7.9 & 6.6 & 7.9 & 7.0 \\
\hline Compost $\left(\mathrm{C}_{24}\right)$ & 10.7 & 13.3 & 11.4 & 9.4 & 11.4 & 10.5 \\
\hline Compost $\left(\mathrm{C}_{48}\right)$ & 12.8 & 15.1 & 12.5 & 10.7 & 13.3 & $\mathbf{1 1 . 4}$ \\
\hline \multicolumn{7}{|c|}{ Proline - spray , $2 \mathrm{~m} / \mathrm{L}\left(\mathrm{P}_{1}\right)$} \\
\hline Control $\left(\mathrm{C}_{0}\right)$ & 9.4 & 11.6 & 10.2 & 7.4 & 9.8 & 8.9 \\
\hline Compost $\left(\mathrm{C}_{24}\right)$ & 11.0 & 13.8 & 11.9 & 9.8 & 12.1 & 10.6 \\
\hline Compost $\left(\mathrm{C}_{48}\right)$ & 13.2 & 15.9 & 13.9 & 11.1 & 13.9 & 12.3 \\
\hline \multicolumn{4}{|c|}{$L S D$ at (0.05): $I * C \times P=n s$} & \multicolumn{3}{|c|}{$L S D$ at $(0.05): I^{*} C{ }^{*} P=n s$} \\
\hline
\end{tabular}

Mean values of the individual effects of the experimental factors.

\begin{tabular}{|c|c|c|c|c|c|c|c|c|c|c|c|}
\hline \multicolumn{6}{|c|}{$1^{\text {st }}$ cut $\left(M g h a^{-1}\right)$} & \multicolumn{6}{|c|}{$2^{\text {nd }}$ cut $\left(M g h a^{-1}\right)$} \\
\hline \multicolumn{2}{|c|}{$\begin{array}{l}\text { Compost } \\
\text { (C) }\end{array}$} & \multicolumn{2}{|c|}{$\begin{array}{l}\text { Irrigation } \\
\text { (I) }\end{array}$} & \multicolumn{2}{|c|}{$\begin{array}{l}\text { Proline } \\
\text { (P) }\end{array}$} & \multicolumn{2}{|c|}{$\begin{array}{l}\text { Compost } \\
\text { (C) }\end{array}$} & \multicolumn{2}{|c|}{$\begin{array}{l}\text { Irrigation } \\
\text { (I) }\end{array}$} & \multicolumn{2}{|c|}{$\begin{array}{l}\text { Proline } \\
\text { (P) }\end{array}$} \\
\hline$\left(\mathrm{C}_{0}\right)$ & 9.43 & $\left(I_{25 \%}\right)$ & 10.80 & $\left(P_{0}\right)$ & 11.24 & $\left(\mathrm{C}_{0}\right)$ & 7.93 & $\left(I_{25 \%}\right)$ & 9.17 & $\left(P_{0}\right)$ & 9.80 \\
\hline$\left(\mathrm{C}_{24}\right)$ & 12.01 & $\left(I_{50 \%}\right)$ & 13.25 & $\left(P_{1}\right)$ & 12.32 & $\left(\mathrm{C}_{24}\right)$ & 10.63 & $\left(I_{50 \%}\right)$ & 11.4 & $\left(\mathbf{P}_{1}\right)$ & 10.66 \\
\hline
\end{tabular}


M.H. Abdel-Aal, et al.,

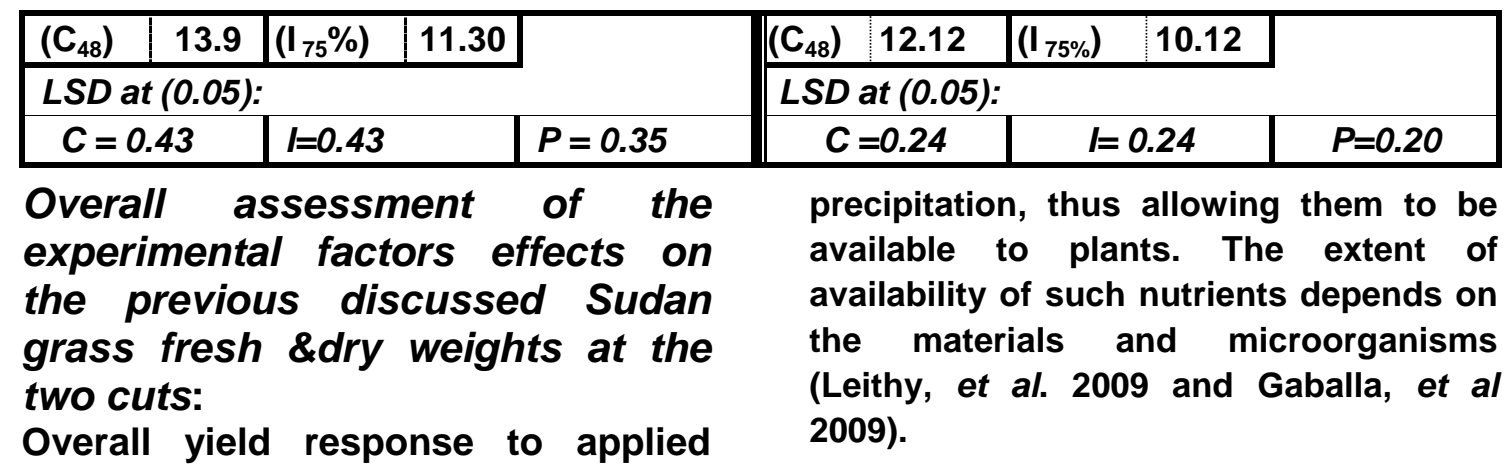
treatments.

The highest yield of irrigation treatments resulted by applying $I_{50 \%}$ followed by $\mathrm{I}_{75 \%}$ then $\mathrm{I}_{25 \%}$ with superiority ranging from about 12 to as much as 47 $\%$ indicates that the medium irrigation of $I_{50 \%}$ was most suitable for crop growth. Irrigation treatment of $I_{50 \%}$ depletion of available moisture renders plants subjected to neither moisture stress nor moisture excess. Allowing plants to face depletion of available water until reaching depleting as much as $75 \%$ of available water (the $\mathrm{I}_{75 \%}$ treatment) will cause that the plants sever from high as well soil salinity. Plant facing moisture stress would suffer some decrease in growth.

These results may be due to; irrigation treatment $\left(\mathrm{I}_{25 \%}\right)$ must have led to oxygen stress in its rhizosphere $\left(\mathrm{I}_{25 \%}\right)$. Nitrogen loss, either by leaching or de-nitrification could have occurred in $\mathrm{I}_{25 \%}$ treatment.

Proline spray alleviated the negative effect of soil salinity and moisture stress particularly under saline conditions (Wahed, et al. 1983).

Applying composts improves the fertility of the clay soils and is reflected by a considerable increase in plant growth (Yaduvanshi (2003). Positive response to compost is a function of increased water retention, field capacity and soil water availability. Organic matter addition incurs addition of active substances such as fulvic and humic acids retain some nutrients, such as $\mathrm{Mn}$ and $\mathrm{Fe}$, and preventing them from

\section{Conclusion:}

In order to improve the productivity of clay soils, a package of agriculture practices should be applied in order to encounter the adverse effects of soil salinity on crop production. This package includes irrigation intervals to allow suitable aeration and water availability. Also compost and proline spray should be included. Values of soil physical and chemical properties tend to be more appropriate for better Sudan grass production in case of better water management. This issue maximizes the beneficial effects of the compost application or the sprayed proline. Moreover, it furnishes suitable conditions in soil which would accelerate the decomposition of organic matter which results increasing the soil water retention content.

\section{REFERENCES}

Abdel-Aal, A. S. I., M. A. Abdel-Hamid, S.A. Ismaiel, A. Abdel Fattah and A.S. Aalab (2003). Effect of organic farming practice on nutrient availability and wheat yield grown on torripsamments. Egypt. J. Soil Sci. 43 (1): 47-62.

Abdel-Moez, M.R., M.H. Ghali and A. Abdel-Fattah (1995). Conditioning of sandy soil by organic wastes and its impact on $\mathrm{N}$-concentration and yield of broad bean.Zagazig, J. Agric. Res. (22): 1145-1155.

Abdel-Wahab, A.F.M. (1999). Iron zinc organic wastes interactions and their effects on biological nitrogen fixation 
in newly reclaimed soils. Ph.D. Thesis, Fac. of Agric. Ain-Shams Univ. Egypt.

Abou-Bakr, N. H.A. (2008). Effect of organic fertilization on reducing pollution and rationalization of irrigation water in Egypt and Libya. Ph.D. Thesis, Institute of African studies, Cairo, Univ. Egypt.

Ashraf, M. and M.R. Foolad (2007). Roles of glycine betaine and proline in improving plant abiotic stress resistance. Environmental and Experimental Botany, 59: 206-216

Aziz, M.A., M.F.A. Sallam, A.M. El-Gendy and M. Abd El-Moniem (1999). Some physical and hydrological properties of sandy soil of inshas as affected by conditioning and irrigation conditions. Egypt .J. Soil Sci. 39 (4):531.

Badawi, F.S.F. (2003). Studies on Bio organic fertilization of wheat under newly reclaimed soils. Ph.D. Thesis, Fac. of Agric. Cairo Univ. Egypt. pp. 917-934.

Basyouny, E.A., S.M. Gawish and S.S. Behairy (2004). Response of plants grown on sandy soil to organic and mineral fertilization. Egypt. J. Appl. Sci: 19 (3): 375-387.

Black, G.R., D.D. Evans, L.E. Ensminger, J.L. White and F.E. Chark (1965). "Methods of soil analysis" Agron. Series, AM. Agron., Madison, Wisconsin, USA.

Bulluck, L.R., M. Brosius, G.K. Evanylo and J.B. Ristaino (2002). Organic and synthetic amendments influence soil microbial, physical and chemical properties on organic and conventional farms. Applied Soil Ecol. 19: 147-160.

Charreau, A. and R. Nicou (1971). Amelioration duprofilcultureldans les sols sableaux el sabcoagrileux du la zone tropicalesectie. QuestAfricaneetses incidence agronomiques. Agron trop. (France) 26: 565-631.
El-Naggar, E.M.A. (1996). Effect of application some organic residues to sandy and calcareous soils on growth and composition of some plants. M.Sc. Thesis, Fac. Agric. Mansoura Univ. Egypt.

Gaballa, A.B., E.E. Abd-EL-Moula and O. A. EL-Toumi (2009). Response of barley plants to organic manure and nitrogen fertilization under Libyan soils condition. African Crop Science Conference Proceedings., (9):175 177.

Gouda, M.A. (1984). Soil and water management of sandy soil. Ph.D. Thesis, Fac. of Agric. Zagazig. Univ. Egypt.

Hamidi, M.A. (1997). Effect of salinity level and soil moisture content on transformation of some nitrogen fertilizers in alluvial soils. M. Sc. Thesis, Fac. Agric. Cairo, Univ. Egypt.

Hamouda, A.M.M., Sh.M. Abd El- Rasoul and H.I. El-Desouky (1999). Shale treatment and its short-term effect on sandy soil characteristics and yield of peanut and wheat. Egypt. J. Soil Sci. 39(2):187

Hillel, D. (1982). Introduction to soil physics $2^{\text {nd }}$ ed. Academic Press, Inc.New York.

Ibrahim, P., P. Ebrahim, N. Payam, M. Abdolamir and O. Kourosh (2011). The effect of compost leachate on pH, EC and soil organic matter in the gavart region of Isfahan. Adv. Environ. Biol., 5(4):624-630.

Las Torres-Tomejil, C.F.A. (2008). Physical and chemical properties in soils in conversion to organic management. Inter. Meeting on Soil Fertility Land Management and Agro climatology.Turkey, p.125-133.

Leithy, S., M.S. Gaballah and A.M. Gomaa (2009). Associative impact of bio an organic fertilizers on geranium plants grown saline conditions. Inter. J. of Acade. Res. 1(1):17-23. 
Matysik, J., B. Alai Bhalu and P. Mohanty (2002). Molecular mechanisms of quenching of reactive oxygen species by proline under stress in plants. Current Science, 82: 525-532.

Mbah, C.N. and E.U. Onweremadu (2009). Effect of organic and mineral fertilizer inputs on soil and maize grain yield in an acid Ultisol in Abakaliki south eastern Nigeria. J. Agron. 2 (1):07-12.

Mbagwu, J.S.C. (1992). Improving the productivity of Nigerian typicHaplustult amended with fresh and a degraded Ultisol in Nigeria using organic and burnt rice-mill wastes. Biore. Technol., 76: 265-272. inorganic amendments. Part 2 changes in physical properties. Biores Technol. 42: $169-175$

Mekail, M. M. (1994). Studies on the use of some organic amendments for coarse textured soil. Ph. D. Agric., Univ. Agric. Sci., Bangalore, India.

Modaihsh, A. S., A. A. Taha and M.O. Mahjoub (2005). Impact of some compost on wheat plant grown in calcareous soils. J. Agric. Sci. Mansoura Univ. Egypt. 30: (12) 83138321.

Patra, D.D., M. Anwar, S. Chand and D.V. Singh (1992). Fertil. Res. 32:327. (C.F. Patra, D.D. Kumar, A. N. and Singh, D.V. 1996. Nitrogen transformation in salt affected soils. J. Indian Soc. Soil Sci. 44 (1): 151-153).

Piper, C.S. (1950). Soil and plant analysis International Public Inc., New York.
Rehan, M.G., A.H. El Sayed, M.M. Hassan and M.A. Negm (2004). Direct and residual effect of mixing the added compost to calcareous soil with sulphur and phosphorus on crop yields and some soil properties. J. Agric. Sci. Mansoura Univ. Egypt. 29 (3): 1603 - 1614.

Sarker, M.C., M. Singh and J. Nath (1992). Influence of farmyard compost on soil structure and some related soil properties. Indian Sco. Soil Sci. 21: 227-229

Singer, J.W., K.A. Kohler, M. Liebman, T.L. Richard, C.A. Cambardella and D.D. Buhler (2004). Tillage and compost affect yield of corn, soybean and wheat and soil fertility. Agron. J. 96:531-537.

Soltanpour, P.N. (1985). Use of ammonium bicarbonate DTPA soil test to evaluate elemental availability and toxicity. Commun. Soil Sci. Plant Anal. 16: 323-318.

Wahid, A., S. Akhtar, A. Iftikhar and E. Rasul (1998). Amelioration of salinesodic soils with organic matter and their use for wheat growth. Commun. Soil Sci. Plant Anal. 29 (15-16): 2307 2318.

Yaduvanshi, N.P.S. (2003). Substitution of inorganic fertilizers by composts and the effect on soil fertility in a ricewheat rotation on reclaimed sodic soil in India. The J. of Agric. Sci. 140:161168. 
تاثير استخدام معدلات مختلفة من السماد العضوى ، البرولين و الرى على بعض خواص التربة و حشيشة السودان الناميه في ارض ملحية.

محمد حافظ عبد العال ، دعاء موسى خليفة ، ابراهيم محمد عبدالله معهز بحوث الأراضى والمياه والبيئة-مركز البحوث الزراعية (مصر - الجيزة)

الملخص العربى اقيمت تجربـة حقلية فى محطة بحوث سـهل الحسينية بمحافظة الثرقية خلال الموسم الزراعى 2017 وهى تجريـة عملية تضمنت ثلاث عوامل كالتالي

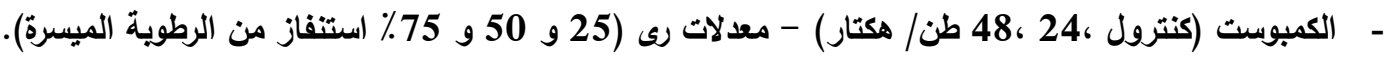

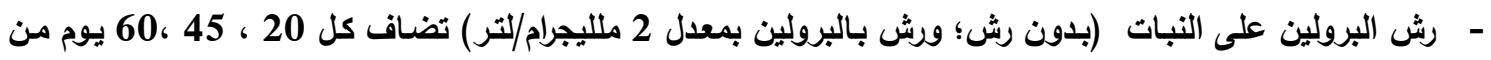

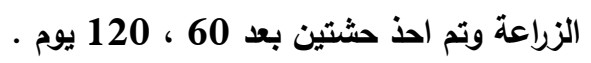
ويهدف البحث لاراسة إمكانية تحسين بعض الخصائص الكيميائية والفيزيائية للتربة الطينية المتأثرة بالأملاح من خلال

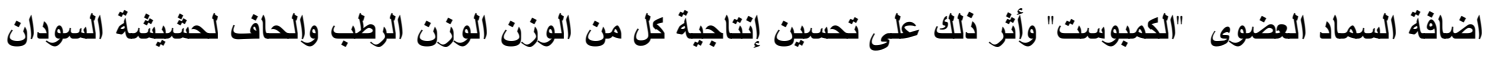

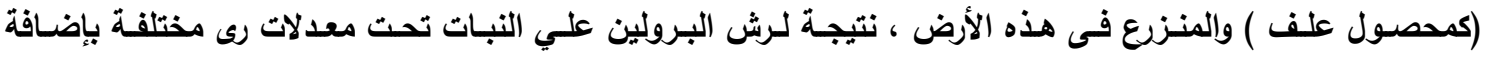
الكومبست. ويمكن تلخيص النتائج المتحصل عليها في ما يلي:

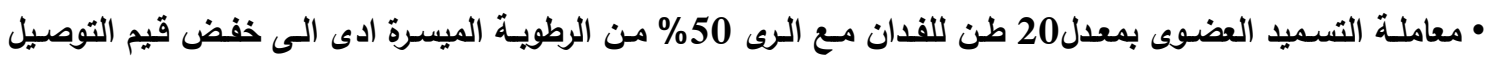
الكهزبى سواء ذللك تحت معاملة البرولين او بدونه. • أوضحت النتائج ان المادة العضوية في التربة زادت بزيادة معدل التسميد العضوى وكانت افضل التهل النتائج باضافة 48 طن

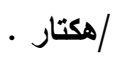
• حدثت زياده فى قيم النتروجين ، الفوسفور و البوتاسيوم الميسر في الترية تحت معاملة الرى عند استنزف 50\% من

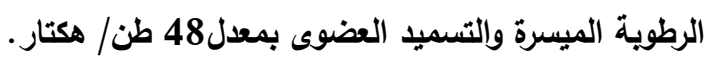

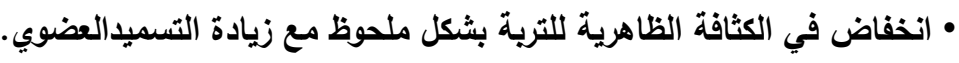

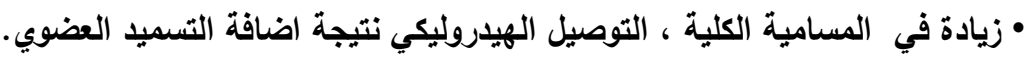

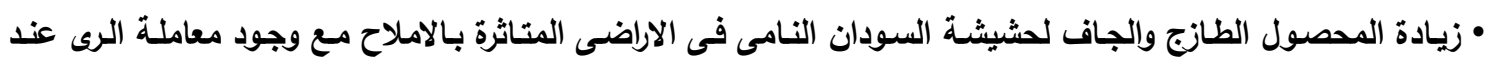

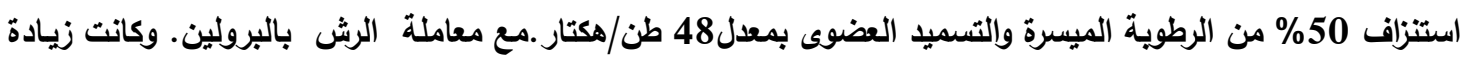
المحصول في الوزن الجافة حوالي 24٪ فى الحثة الاولي مقارنة بالحثة الثانية. 
M.H. Abdel-Aal, et al.,

أسماء السادة المحكمين

أ.د/ طارق عبدالرحمن أبوالضيفان معهـ بحوث الأراضى والمياه والبيئة - مركز البحوث الزراعية

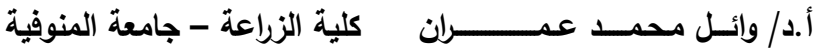

